\title{
Analisis Peranan dan Penggunaan Media Sosial dalam Mengomunikasikan Informasi di Komunitas 234SC Jakarta Utara
}

\author{
Ishak Winaldo Liubana ${ }^{1}$, Yugih Setyanto ${ }^{2 *}$ \\ 1Fakultas Ilmu Komunikasi, Universitas Tarumanagara \\ Email: ishakwinaldo@gmail.com \\ 1Fakultas Ilmu Komunikasi, Universitas Tarumanagara* \\ Email: yugihs@fikom.untar.ac.id
}

Masuk tanggal : 15-12-2021, revisi tanggal : 06-01-2022, diterima untuk diterbitkan tanggal : 16-01-2022

\begin{abstract}
Social community is a community that is formed on the basis of high social awareness. One of the social communities in Jakarta is 234 Solidarity Community (234 SC). This community is a social community that is engaged in the social, automotive, cultural, and sports fields. Before entering the current modern era, the formation of a community depended on motion audio-visual media such as television, audio media such as radio and print media such as newspapers, magazines, brochures. But now internet-based media has become an alternative choice, including social media. The role and use of social media in the community is also important to provide information about the community's vision and mission to its members. The purpose of this study was to determine the role and use of social media in communicating information to the community of 234 SC North Jakarta. The research method used by researchers in this study is to use qualitative methods. The data analyzed is in the form of descriptive and not in the form of numbers. As a result, social media is very effective as a medium to disseminate information and missions to its members.
\end{abstract}

Keywords: 234SC North Jakarta, community, social media

\begin{abstract}
Abstrak
Komunitas sosial adalah komunitas yang terbentuk atas dasar kesadaran sosial yang tinggi. Salah satu komunitas sosial yang ada di Jakarta adalah 234 Solidarity Community (234 SC). Komunitas ini merupakan suatu komunitas sosial yang bergerak dalam bidang sosial, otomotif, budaya, dan olahraga. Sebelum memasuki era modern saat ini, pembentukan suatu komunitas bergantung pada media audio visual gerak seperti televisi, media audio seperti radio dan media cetak seperti koran, majalah, brosur. Namun kini media berbasis internet menjadi alternatif pilihan, termasuk media sosial. Peranan dan penggunaan media sosial dalam komunitas juga penting dilakukan untuk memberikan informasi tentang visi misi komunitas kepada anggotanya. Tujuan dalam penelitian ini adalah mengetahui peranan dan penggunaan media sosial dalam mengkomunikasikan informasi komunitas 234 SC Jakarta Utara. Adapun metode penelitian yang digunakan peneliti dalam penelitian ini adalah dengan menggunakan metode kualitatif. Data yang dianalisis berbentuk deskriptif dan bukan berupa angka. Hasilnya, media sosial sangat efektif sebagai medium mensosialisasikan informasi maupun misi bagi anggotanya.
\end{abstract}

Kata Kunci: 234SC Jakarta Utara, komunitas, media sosial

\section{Pendahuluan}

Komunitas merupakan suatu kelompok yang di dalamnya setiap anggota disatukan oleh persamaan visi dan misi serta tujuan. Hal tersebut dapat di lihat pada 
komunitas-komunitas yang ada di sekitar yang terbentuk berdasarkan kesamaan yang mereka miliki, mulai dari kesamaan hobi, sehingga terbentuk komunitas sosial, komunitas motor, komunitas budaya, dan komunitas-komunitas lain. Menurut Soerjono (dalam Ihsanullah, 2016) komunitas dibentuk bukan tanpa tujuan. Bisa tujuan jangka pendek, menengah, atau jangka panjang. Beberapa tujuan dibentuknya komunitas yang layak diketahui adalah sebagai berikut:

1. Menetapkan tujuan Komunitas muncul ketika manusia itu membutuhkan kehidupan yang layak, untuk menciptakan suatu komunitas yang baik, mereka harus mengetahui untuk apa komunitas tersebut didirikan, dan untuk siapa komunitas itu didirikan.

2. Menciptakan tempat berkumpul yang nyaman dimana setiap individu saling bertemu, bertukar pendapat, saling bercerita tentang masalah masalah yang mereka alami, dengan adanya saling rasa kepercayaan tersebut akan menimbulkan suatu rasa kekeluargaan yang hinggap di setiap individu.

3. Menyalurkan hobi Kehidupan manusia tidak lepas dari yang namanya hobi atau biasa disebut dengan kesukaan masing masing person. Disinilah funsi diciptakannya suatu komunitas, dimana tempat mereka yang mempunyai hobi yang sama berkumpul, membicarakan sesuai hobi hobi mereka.

4. Menciptakan keluarga yang baru Manusia tidak dapat berdiri sendiri, dalam artian manusia tidak bisa hidup tanpa orang lain, manusia membutuhkan orang lain dalam pengaplikasiannya terhadap kehidupan. Dalam hal ini, komunitas bertujuan agar setiap individu memiliki rasa kepemilikan bersama dengan cara kekeluargaan, sehingga secara tidak disadari kelompok tersebut memiliki keluarga yang berbeda dari keluarga kandung.

5. Media Ekspresi Jati Diri Komunitas sebagai tempat berkumpul juga bisa dijadikan salah satu media untuk menunjukan jati diri. Secara psikologi, perilaku pencarian jati diri mayoritas dilakukan oleh remaja. Tak heran jika mereka lebih sering bergabung dengan komunitas atau teman-teman yang mempunyai kesamaan, baik bentuk komunitasnya legal, ilegal, baik, dan buruk.

Selain itu, komunitas sosial juag merupakan komunitas yang terbentuk atas dasar kesadaran sosial yang tinggi. Komunitas sosial adalah organisasi non profit yang didalamnya setiap anggota merumuskan visi, misi, serta tujuan komunitas dan merealisasikan visi, misi, serta tujuan tersebut ke dalam tindakan nyata. Salah satu komunitas sosial yang ada di Jakarta adalah 234 Solidarity Community (234 SC). 234 Solidarity Community merupakan suatu komunitas sosial yang bergerak dalam bidang sosial, otomotif, budaya, dan olahraga. 234 SC memiliki sayap yang begitu lebar dan membuatnya begitu dikenal dan dipandang oleh banyak orang sehingga menimbulkan ketertarikan, sehingga banyak orang umum berminat untuk bergabung dalam 234 SC.

Visi \& misi 234 SC sendiri adalah mempersatukan pemuda-pemudi untuk menjadikan bagian dari sebuah keluarga besar dan memiliki tingkat solidaritas yang tinggi. Inti dari kegiatan 234 SC adalah untuk melakukan hal-hal yang positif dalam berbagai bidang seperti sosial, budaya, olah raga, maupun kepemudaan, serta menjaga silahturahmi dan mempererat persatuan dan kesatuan anak-anak muda bangsa Indonesia yang memiliki nasionalisme tinggi. Sebagai organisasi dengan anggota yang tidak sedikit, 234 SC mencoba memanfaatkan media sosial untuk berkomunikasi, baik secara internal maupun eksternal. 
Media sosial sendiri merupakan media online. Dengan media ini pengguna dapat dengan mudah berpartisipasi, berbagi dan menciptakan isi meliputi blog, jejaring sosial, wiki, forum dan dunia virtual. Media sosial mengajak siapa saja yang tertarik untuk berpertisipasi dengan memberi kontribusi dan feedback secara terbuka, memberi komentar, serta membagi informasi dalam waktu yang cepat dan tak terbatas. Di era yang serba modern ini peran dan penggunaan media sosial sangat penting digunakan dalam komunitas sehingga pengenalan suatu komunitas terhadap khalayak luas dapat diketahui dengan cepat. Peranan dan penggunaan media sosial dalam komunitas juga penting dilakukan untuk memberikan informasi tentang visi dan misi, serta tujuan sebuah komunitas.

Berdasarkan uraian diatas, peneliti tertarik untuk melakukan penelitian tentang peranan dan penggunaan media sosial dalam mengkomunikasikan informasi komunitas 234 SC Jakarta Utara.

\section{Metode Penelitian}

Penelitian ini dilakukan untuk mengetahui bagaimana peranan dan penggunaan media sosial dalam mengkomunikasikan informasi komunitas 234 SC Jakarta Utara. Dalam penelitian ini peneliti menggunakan penelitian kualitatif dengan metode Case Study Research atau studi kasus. Dalam buku Metode Penelitian Kualitatif untuk Ilmu-Ilmu Sosial dijelaskan bahwa studi kasus adalah suatu model yang menekankan pada eksplorasi dari suatu system yang terbatas pada suatu kasus atau beberapa kasus secara mendetail, disertai dengan penggalian data secara mendalam yang melibatkan beragam sumber informasi yang kaya akan konteks (Herdiansyah, 2010:76). Dalam mengetahui peranan dan penggunaan media sosial di dalam komunitas dibutuhkan konsep yang tepat. Seperti dikemukakan Shirky, Body, dan Van Djik (Nasrullah, 2017), bahwa media sosial berperan sebagai:

1. Merupakan alat untuk meningkatkan kemampuan pengguna untuk berbagi (to share), bekerja sama (to co-operate) di antara pengguna dan melakukan tindakan secara kolektif yang semuanya berada di luar kerangka institusional maupun organisasi.

2. Media sosial sebagai kumpulan perangkat lunak yang memungkinkan individu maupun komunitas untuk berkumpul, berbagi, berkomunikasi, dan dalam kasus tertentu saling berkolaborasi atau bermain.

3. Media sosial adalah platform media yang memfokuskan pada eksistensi pengguna yang memfasilitasi mereka dalam beraktivitas maupun berkolaborasi.

\section{Hasil Temuan dan Diskusi}

Penulis melakukan wawancara dengan ketua 234SC Jakarta Utara yaitu Alvin Febryan, mengenai proses komunikasi yang terjadi di dalam komunitas 234SC Jakarta Utara dalam menjaga kesamaan pemahaman dalam komunitas.

Salah satu potongan wawancara dengan Alvin Febryan mengenai kesulitan dalam mengoordinasikan setiap informasi setelah menjadi ketua 234SC Jakarta Utara

“Agak-agak susah sih ya, soalnya kita ini kan komunitas besar, apalagi kita ini jangkauannya satu Indonesia. Nah, agak rumitnya kadang terjadinya miss communication antara wilayah dan pusat. Jadi dari pusat datanya gimana, 
turun ke koorwil, turun lagi ke regwil, tapi itu semua kan bisa dikoordinasikan dengan medsos, sih".

Pernyataan tersebut dapat diartikan bahwa kemampuan atau kapasistas dan pengalaman dapat memungkinkan manusia untuk menjadi objek bagi dirinya sendiri. Kemampuan manusia untuk menjadi objek bagi dirinya sendiri muncul apabila manusia mampu untuk mengambil peran orang lain dalam lingkungan sosial dimana ia berada. Hal tersebut dibuktikan dengan status atau jabatan yang ada pada Alvin Febryan yang mengambil peran sebagai ketua komunitas 234SC wilayah Jakarta Utara.

"Contohnya kayak misalnya, kita kan kadang melakukan kopdar. Kopdar itu bisa dilakukan secara internal, region wilayah, atau juga gabungan nih dari koordinator wilayah Jakarta. Terdiri dari Jakarta Barat, Jakarta Pusat, Jakarta Selatan, Jakarta Timur, dan Jakarta Utara. Jadi kalo informasinya dikirim nih dari Korwil ke Regwil, biasanya kita saring dulu ke grup pengurus, nah nanti baru kita saring lagi ke grup besar, keluarga besar 234SC Jakarta Utara.”

Pernyataan dari narasumber tersebut berkaitan dengan unsur-unsur yang ditemui dalam teori komunitas yang dimana menurut Soerjono (Ihsanullah, 2016), komunitas diciptakan untuk menciptakan keluarga baru, memiliki rasa kepemilikan bersama dengan cara kekeluargaan, sehingga secara tidak disadari kelompok tersebut memiliki keluarga yang berbeda dari keluarga kandung. 234SC Jakarta Utara merupakan komunitas yang berada di wilayah Jakarta Utara dan juga sebagai tempat berkumpulnya pemuda-pemudi yang memiliki tingkat solidaritas yang tinggi. Terlebih 234SC Jakarta Utara membuka dan mempersilahkan siapapun atau untuk umum untuk bergabung di dalam komunitas ini. 234SC ini juga banyak melakukan kegiatan berguna lainnya, dan membantu masyarakat di dalam situasi apapun.

"Biasanya untuk miss communication yang terlalu jauh biasa melalui WhatsApp. Japri gitu, loh, biar lebih baik."

Seperti yang dikatakan Alvin, media sosial dapat digunakan untuk mengatasi sebuah miss communication. Dimana kita dapat bekerja sama (to co-operate) antar pengguna dan melakukan tindakan secara kolektif. Hal itu dapat dilakukan atau dikomunikasikan hanya melalui media sosial saja. Informasi tersebut diolah dahulu agar tidak terjadinya kesalahpahaman dan tetap menjaga kesamaan pemahaman dalam komunitas. Kemudian dalam wawancara, Alvin mengatakan:

"Jadi anak-anak muda nih, kita tempat bernaungnya anak-anak muda yang punya bakat atau keinginan lebih, lah, untuk berbuat untuk masyarakat atau buat untuk Negara bisa nih bergabung di 234SC Jakarta Utara"

Tanggapan tersebut sejalan dengan teori Soerjono yang dimana komunitas menciptakan tempat berkumpul yang nyaman Dimana setiap individu saling bertemu, bertukar pendapat, saling bercerita tentang masalah masalah yang mereka alami, dengan adanya saling rasa kepercayaan tersebut akan menimbulkan suatu rasa kekeluargaan yang hinggap di setiap individu. 
Selain itu dapat diartikan sebagai kekerabatan, persaudaraan, dan solidarisme antar anggota dalam suatu komunitas dalam melakukan tujuan tertentu. Tujuan komunitas 234SC adalah untuk menciptakan solidaritas yang tinggi antar anggota dalam melayani dan menjaga silaturahmi seluruh masyarakat Indonesia. Selain itu dapat diartikan juga sebagai tempat untuk mengekspresikan diri. Jadi di dalam komunitas ini, anggota dapat mengekspresikan jati dirinya.

"Ada otomotif juga, ada olahraga juga, jadi yang emang anak-anak muda nih, yang berbakat nih, kaya mungkin temen $l u$ yang berbakat di futsal, nanti juga kita bisa biayain untuk sekolah futsal atau sekolah apanya gitu, loh, jadi dapet beasiswa gitu, loh, ga cuman nongkrong Cuma-cuma gitu, lho."

234SC Jakarta Utara menciptakan tempat atau komunitas yang mendukung bakat atau kemampuan dari anggotanya dalam suatu bidang tertentu. Hal tersebut dapat dilihat melalui ekpresi diri, talenta yang dimiliki melalui hobinya, serta keinginan yang dimiliki.

Oleh karena itu 234SC menjadi salah satu komunitas yang begitu dikenal dan dipandang oleh banyak orang sebab visi dan misi 234SC sendiri adalah mempersatukan pemuda-pemudi untuk menjadikan bagian dari keluarga besar dan memiliki tingkat solidaritas yang tinggi. Intinya kegiatan yang dilakukan oleh 234SC haruslah bersifat positif dalam berbagai bidang seperti sosial, budaya, olahraga, minat, maupun kepemudaan.

\section{Simpulan}

Berdasarkan hasil pembahasan di temui berbagai fakta yang ada bahwa komunitas 234SC Jakarta Utara menggunakan media sosial dengan sebaik mungkin untuk mengkomunikasikan informasi kepada seluruh anggotanya, yang dimana informasi yang ada disaring terlebih dahulu oleh para pengurus, lalu kemudian setelah dinyatakan valid informasi tersebut baru dikirimkan kepada keluarga besar 234SC Jakarta Utara.

Hal itu sependapat dengan teori Boyd, yang dimana media sosial sebagai kumpulan perangkat lunak yang memungkinkan individu maupun komunitas untuk berkumpul, berbagi, berkomunikasi, dan dalam kasus tertentu saling berkolaborasi atau bermain. Selain itu juga 234SC menggunakan media sosial untuk memberikan informasi yang berkaitan dengan berbagai bidang. Baik dalam bidang atau aspek sosial dan budaya ataupun bidang atau aspek hobi atau ekspresi diri. Di komunitas 234SC Jakarta Utara, para anggota diperbolehkan untuk berkumpul secara internal, regwil, maupun wilayah untuk melakukan kegiatan bersama-sama.

Komunitas ini juga berperan penting karena pada fakta dari data wawancara yang penulis lakukan, komunitas 234SC Jakarta Utara menjadi satu sosok atau contoh komunitas yang membantu masyarakat yang kurang beruntung. Komunitas harus memiliki tujuan yang baik karena komunitas dibuat untuk menciptakan suatu hal yang baik. Harus tau untuk apa komunitas itu didirikan, dan untuk siapa komunitas itu didirikan. Hal ini juga sependapat dengan teori Soerjono yaitu komunitas dibentuk bukan tanpa tujuan. 


\section{Ucapan Terima Kasih}

Ucapan terima kasih diberikan kepada Fakultas Ilmu Komunikasi Universitas Tarumanagara, responden penelitian, keluarga, teman-teman, dan seluruh pihak yang membantuk peneliti dalam menyempurnakan penelitian ini.

\section{Daftar Pustaka}

Herdiansyah, Haris. (2010). Metode Penelitian Kualitatif untuk Ilmu-ilmu Sosial. Jakarta: Salemba Humanika.

Ihsanullah, Muhammad. (2016). Analisis Modal Sosial Pada Himpunan Pelajar Mahasiswa Pelalawan (Hipmawan) Di Pekanbaru. Jom Fisip Vol. 3 No. 2. 115.

Nasrullah, Rulli. (2017). Media Sosial: Perspektif Komunikasi, Budaya, dan Sosioteknologi. Bandung:Remaja Rosdakarya. 